\title{
Catalytic Synthesis of a New Series of Alkyl Uronates and Evaluation of Their Physicochemical Properties
}

\author{
Huiling Lu ${ }^{1}$, Audrey Drelich ${ }^{1}$, Mehdi Omri ${ }^{2}$, Isabelle Pezron ${ }^{1}$, Anne Wadouachi ${ }^{2}$ \\ and Gwladys Pourceau ${ }^{2, *}$ \\ 1 TIMR EA 4297 UTC /ESCOM, Sorbonne University, University of Technology of Compiègne, \\ Rue Personne de Roberval, Compiègne CEDEX 60200, France; huiling.lu@utc.fr (H.L.); \\ audrey.drelich@utc.fr (A.D.); isabelle.pezron@utc.fr (I.P.) \\ 2 LG2A, UMR CNRS 7378-Chemistry Institute of Picardy FR CNRS 3085, University of Picardy Jules Verne, \\ 33 rue Saint Leu, Amiens CEDEX 80039, France; mehdi.omri@u-picardie.fr (M.O.); \\ anne.wadouachi@u-picardie.fr (A.W.) \\ * Correspondence: gwladys.pourceau@u-picardie.fr; Tel.: +33-032-282-7476
}

Academic Editors: Christophe Len and Derek J. McPhee

Received: 27 July 2016; Accepted: 22 September 2016; Published: 28 September 2016

\begin{abstract}
Large quantities ( $>3 \mathrm{~g}$ ) of a new series of alkyl uronates were synthesized in two steps from commercial methyl hexopyranosides. Firstly, several tens of grams of free methyl $\alpha-\mathrm{D}-$ glucopyranoside were selectively and quantitatively oxidized into corresponding sodium uronate using 2,2,6,6-tetramethyl-1-piperidinyloxy free radical (TEMPO)-catalyzed oxidation. Hydrophobic chains of different length were then introduced by acid-mediated esterification with fatty alcohols (ethyl to lauryl alcohol) leading to the desired alkyl glucuronates with moderate to good yields (49\%-72\%). The methodology was successfully applied to methyl $\alpha$-D-mannopyranoside and methyl $\beta$-D-galactopyranoside. Physicochemical properties, such as critical micelle concentration (CMC), equilibrium surface tension at CMC $\left(\gamma_{\mathrm{cmc}}\right)$, solubility, and Krafft temperature were measured, and the effect of structural modifications on surface active properties and micelle formation was discussed.
\end{abstract}

Keywords: carbohydrate-based surfactants; uronic acids derivatives; sugar esters; TEMPO mediated oxidation

\section{Introduction}

Carbohydrate-based surfactants, including sugar esters, have recently become more and more attractive because of their renewable origin, biodegradability, non-toxicity, and physicochemical behaviors [1-3]. Among others properties, they are able to reduce the surface tension and to penetrate into lipid bilayers, are highly dispersible, and possess a high emulsifying power [4]. Moreover, some sugar-based surfactants exhibit antimicrobial activities [5]. All of these properties confer on them various applications in food, cosmetic, and pharmaceutical industries [6]. Sugar fatty esters are formed by one or several hydrophilic sugar headgroups and one or several hydrophobic alkyl chains. Due to their biodegradability, they constitute viable eco-friendly alternatives to petroleum-based surfactants [7]. The raw material (saccharides and fatty alcohols or acids) is available from renewable resources and obtained by simple processes: hydrolysis of starch, cellulose, hemicellulose, or pectin furnishes saccharides; steam-splitting of oils furnishes fatty chains. Moreover, the ester linkage between hydrophobic and hydrophilic parts is obtained by a simple esterification or acylation reaction performed by chemical or enzymatic synthetic routes. In the last decades, the interfacial properties of several series of sugar fatty esters have been investigated [8-11]. However, in most studies, anomeric-free carbohydrates are used, leading to mixtures of $\alpha$ and $\beta$ isomers, for which the ratio was not determined. Yet, the configuration $\alpha$ or $\beta$ of the sugar headgroup influences the micellar 
properties $[12,13]$. Thus, if one wants to establish the structure/function relationship between the molecular structure and the physicochemical properties of these sugar esters, it is essential to know exactly the $\alpha / \beta$ ratio or to protect the anomeric position. Moreover, there is still a need to design new sugar-based surfactants with better properties while understanding the impact of some structural modifications on the physicochemical properties. In particular, the ester "direction" $(-\mathrm{C}(\mathrm{O})-\mathrm{O}-\mathrm{R}$, or $-\mathrm{O}-\mathrm{C}(\mathrm{O})-\mathrm{R})$ can play a role on the air-water interface absorption [14]. Furthermore, both the sugar headgroup and the alkyl chain can affect the physicochemical properties of the glycolipids [15-17].

Herein, we propose to synthesize a new series of sugar fatty esters with well-defined structures (as described in Figure 1) and to evaluate their physicochemical properties.

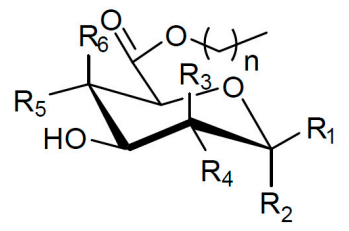

$\alpha$-Glucose derivatives: $\mathrm{R}_{1}=\mathrm{H}, \mathrm{R}_{2}=\mathrm{OMe}, \mathrm{R}_{3}=\mathrm{H}, \mathrm{R}_{4}=\mathrm{OH}, \mathrm{R}_{5}=\mathrm{OH}, \mathrm{R}_{6}=\mathrm{H}, \mathrm{n}=1$ to 11

$\beta$-Galactose derivatives: $\mathrm{R}_{1}=\mathrm{OMe}, \mathrm{R}_{2}=\mathrm{H}, \mathrm{R}_{3}=\mathrm{H}, \mathrm{R}_{4}=\mathrm{OH}, \mathrm{R}_{5}=\mathrm{H}, \mathrm{R}_{6}=\mathrm{OH}, \mathrm{n}=7$

$\alpha$-Mannose derivatives: $\mathrm{R}_{1}=\mathrm{H}, \mathrm{R}_{2}=\mathrm{OMe}, \mathrm{R}_{3}=\mathrm{OH}, \mathrm{R}_{4}=\mathrm{H}, \mathrm{R}_{5}=\mathrm{OH}, \mathrm{R}_{6}=\mathrm{H}, \mathrm{n}=7$

Figure 1. General structure of the proposed sugar fatty esters.

With the aim to lead to viable eco-friendly alternatives to petroleum-based surfactants, the synthesis should be rapid, easy, scalable, and should respect green chemistry principles. The synthetic methodology should also be versatile and applicable to different headgroups and tail lengths. In this study, we synthesized, at the multigram scale, the proposed alkyl 1-methyl-uronates by, firstly, 2,2,6,6-tetramethyl-1-piperidinyloxy free radical (TEMPO)-catalyzed oxidation of methyl glycosides at primary position, followed by a $\mathrm{H}_{2} \mathrm{SO}_{4}$-catalyzed esterification with fatty alcohols.

In order to measure the influence of the headgroup on the amphiphilic properties of this new series of sugar esters, the methodology was applied to different sugars (Man, Gal, Glc) with the same tail lengths as the $C_{8}$ alkyl chain. The role of the hydrophobic tail length was also investigated using incrementally-increased hydrophobic chain lengths $\left(\mathrm{C}_{6}, \mathrm{C}_{8}, \mathrm{C}_{10}\right.$, and $\mathrm{C}_{12}$ fatty alcohols) with an identical headgroup of Glc. The effect of the $\beta$ configuration was studied for one molecule, via the octyl (1- $\beta$-methyl)galacturonate.

It is well known that solubility and surface adsorption properties are critically important aspects for most amphiphilic molecules. These properties, as well as phase diagram, are always influenced by the sugar head for sugar-based surfactants [18]. Amphiphilic molecules are rather convenient for industrial applications if they can dissolve easily at room temperature to a great degree, significantly reduce the surface tension, and have a large area of a soluble micellar phase. The present study is especially interested in the characterization of molecules having a $C_{6}, C_{8}, C_{10}$, and $C_{12}$ alkyl chain, the case for commonly ionic/nonionic used surfactants. Their water solubility and adsorption behavior, including Krafft point, concentration limit of clear solution, surface-tension lowering, and critical micellar concentration in water were studied to explore the influence of some structural factors, i.e., alkyl chain and sugar head.

\section{Results and Discussion}

\subsection{Synthesis}

Due to the electron-withdrawing effect of the C-5 carboxylic group that deactivates the anomeric position, functionalization of uronic acids at the anomeric position is particularly difficult, needing protection/deprotection steps and/or harsh conditions [19]. From our point of view, the best way to obtain the desired alkyl uronates respecting the atom-energy principle, and without the use of 
hazardous reactants/solvents, was to use a two-step protocol starting from commercial methyl glycoside: an oxidation step followed by an esterification reaction. Selective oxidation of primary alcohols remains challenging in carbohydrate chemistry when free carbohydrates are used. Whereas mild oxidants, such as Swern reagent or Dess-Martin periodinane, have been developed, regioselective oxidation of the primary hydroxyl group in the presence of the secondary ones is difficult. Therefore, the application of these reagents to polyols generally requires the use of protecting groups and increases the number of synthesis steps. As an environmentally benign and highly-regioselective catalyst, TEMPO and its derivatives, have been well described in the literature since the first report by Lebedev [20]. TEMPO is a stable radical able to oxidize alcohol into aldehyde and/or carboxylic acids in catalytic conditions, but needs to be regenerated in situ by co-catalysts. Various co-oxidants have been explored: $\mathrm{NaOCl} / \mathrm{KBr}$ (Anelli's procedure) [21], $\mathrm{NaOCl} / \mathrm{NaClO}_{2}$ (Zhao's procedure) [22], PhI(OAc) 2 (also known as BAIB: iodobenzene diacetate) (Epp's procedure) among others [23]. Avoiding the introduction/removal of inorganic salts is the major advantage of this latter method. Moreover, Epp's procedure is especially suitable for large-scale reactions and the by-products are the rather innocuous iodobenzene and acetic acid. This was the procedure we chose for the oxidation of several grams of methyl glycoside.

In order to establish the oxidation protocol (Scheme 1(a)), the reaction was first carried out by addition of TEMPO and BAIB to a solution of $1 \mathrm{~g}$ of methyl $\alpha$-glucopyranoside in a water-acetonitrile solution. The reaction was monitored by TLC but, even after two weeks, incomplete oxidation was observed ( 81\% determined by ${ }^{1} \mathrm{H}-\mathrm{NMR}$, Figure $\left.2 \mathrm{~B}\right)$. By performing the reaction in the presence of 1 eq. of $\mathrm{NaHCO}_{3}$, the reaction rate was drastically enhanced and the oxidation was complete within $24 \mathrm{~h}$, as shown by ${ }^{1} \mathrm{H}-\mathrm{NMR}$ (Figure 2C). Indeed, alkaline conditions are known to favor TEMPO-catalyzed oxidations when $\mathrm{NaOCl}$ is used as co-oxidant. However, to our knowledge, in Epp's procedure, no work never reported this particularity. In our case, the addition of $\mathrm{NaHCO}_{3}$ also led to a cleaner crude (almost no peak in the 1-2.5 ppm region). The resulting reaction mixture was quenched using ethanol and concentrated. Sodium (methyl $\alpha$-D-glucopyranosid)uronate (2) was quantitatively obtained as white crystalline solid. These conditions were applied successfully to $5 \mathrm{~g}$, then $15 \mathrm{~g}$, of methyl $\alpha$-glucopyranoside showing a good reproducibility on this substrate. When using methyl $\beta$-D-galactopyranoside and methyl $\alpha$-D-mannopyranoside, although complete oxidations were obtained, the reaction rate was lower ( $48 \mathrm{~h}$ to 8 days were necessary). Considering the relatively clean NMR profiles obtained for the crudes and the difficulty to purify such polar molecules, the resultant crude sodium uronates were directly used for the following reaction, i.e., the esterification step.

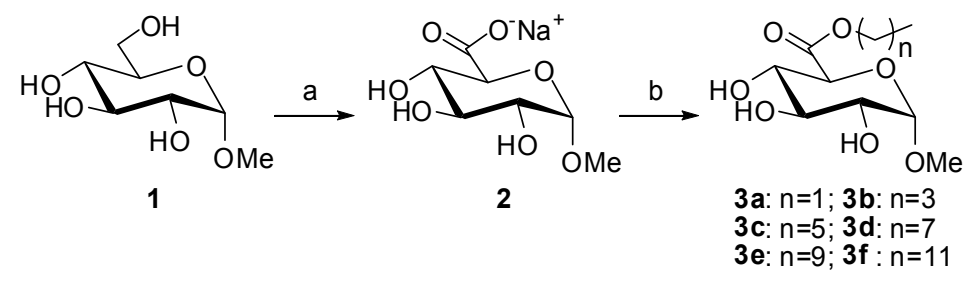

Scheme 1. General procedure applied to methyl $\alpha$-glucopyranoside. Reagents and conditions: (a) TEMPO cat., $\mathrm{BAIB}, \mathrm{NaHCO}_{3}, \mathrm{H}_{2} \mathrm{O} / \mathrm{CH}_{3} \mathrm{CN}, 15 \mathrm{~h}$, RT; and (b) $\mathrm{ROH}, \mathrm{Na}_{2} \mathrm{SO}_{4}, \mathrm{H}_{2} \mathrm{SO}_{4}$ cat., $24 \mathrm{~h}, 65^{\circ} \mathrm{C}$.

Acid-catalyzed esterification of uronic acids is also challenging since, under acidic conditions, (trans)glycosylation and esterification are competitive, leading to several products [24]. Thus, a careful control of the esterification conditions is necessary to avoid by-product formation. Therefore, sodium methyluronates were used directly without exchange for uronic acids and the amount of $\mathrm{H}_{2} \mathrm{SO}_{4}$ was carefully controlled. As shown in Scheme 1(b), sodium 1- $\alpha$-methylglucuronate was first dispersed in the desired alcohol under sonication, sodium sulfate was added as a desiccating agent, and the mixture was warmed to $65{ }^{\circ} \mathrm{C}$. A catalytic amount of $\mathrm{H}_{2} \mathrm{SO}_{4}$ was then added. After $24 \mathrm{~h}$, the reaction was quenched by the addition of $\mathrm{Et}_{3} \mathrm{~N}$, the residual alcohol was removed by evaporation 
or filtration on silica gel (depending on the boiling point of the alcohol), and the crude was purified by chromatography. Only traces of transglycosylated products were observed and the desired alkyl (1- $\alpha$-methyl)glucuronates (3a-3f) were obtained in moderate to good yields $(49 \%-72 \%)$.

(A)

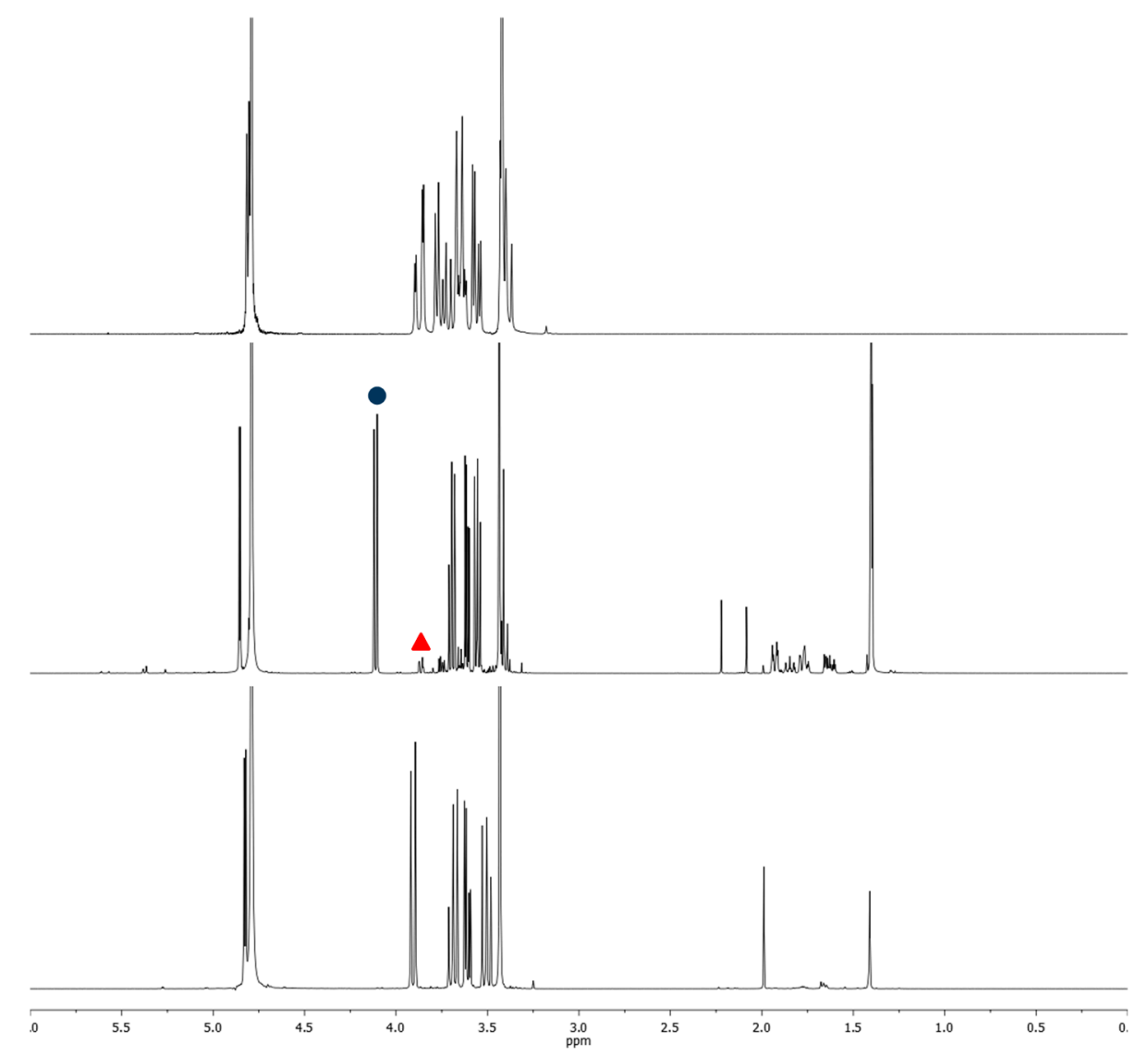

Figure 2. ${ }^{1} \mathrm{H}$-NMR spectra of (A) methyl $\alpha$-glucoside (starting material); (B) crude mixture without $\mathrm{NaHCO}_{3}$ after 17 days, (C) crude mixture with 1 eq. $\mathrm{NaHCO}_{3}$ after $24 \mathrm{~h}$. Comparison between $\mathrm{H}-5$ signal of $\alpha$-methylglucuronic acid $(\boldsymbol{)})$ and H-6 of methyl $\alpha$-glucoside $(\boldsymbol{\Delta})$ allows the evaluation of the conversion. From (B) to (C), the $\mathrm{H}-5$ signal shifted from 4.1 to $3.9 \mathrm{ppm}$ because of the basic $\mathrm{pH}$ (sodium carboxylate instead of carboxylic acid).

To compare the effect of the sugar headgroup on the physicochemical properties, octyl (1- $\beta$ methyl)galacturonate (5) and octyl (1- $\alpha$-methyl)mannuronate (7) were synthesized similarly starting from the corresponding sodium (1- $\beta$-methyl)galacturonate (4) and sodium (1- $\alpha$-methyl)mannuronate (6), respectively $(44 \%-57 \%)$ (Figure 3 ).

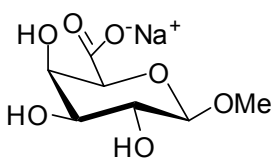

4

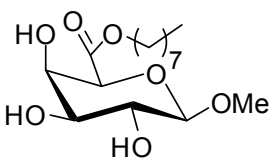

5

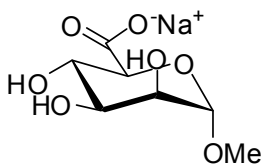

6

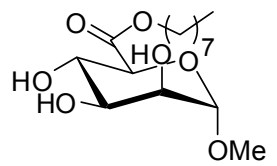

7

Figure 3. Molecular structures of sodium (1- $\beta$-methyl)galacturonate (4), octyl (1- $\beta$-methyl)galacturonate (5), sodium (1- $\alpha$-methyl)mannuronate (6), and octyl (1- $\alpha$-methyl)mannuronate (7). 


\subsection{Aqueous Solubility}

Results obtained from both visual observations and DSC (differential scanning calorimetry) analysis, for this new series of sugar esters, are summarized in Table 1. The appearance of the molecules is also reported. DSC analysis indicates that, solely, two molecules display a phase transition corresponding to a Tk (Krafft Temperature) in the temperature range studied. Corresponding typical DSC cooling curves of the phase transition obtained for these molecules in aqueous solution $(10 \%$ $w / w)$ are displayed in Figure 4. Moreover, the concentration limit of apparently clear solutions at room temperature of about $25^{\circ} \mathrm{C}$ was pointed out for each molecule.

Table 1. Physical parameters related to solubility property for studied molecules.

\begin{tabular}{cccc}
\hline Molecule & $\mathbf{T k}^{\mathbf{a}}\left({ }^{\circ} \mathbf{C}\right)$ & {$[\mathbf{C}]_{\max }$ at $\approx \mathbf{2 5}{ }^{\circ} \mathbf{C}(\mathbf{m M})$} & State \\
\hline Hexyl $(1-\alpha$-methyl)glucuronate 3c & undetected & $50-60$ & wax \\
Octyl $(1-\alpha$-methyl)glucuronate 3d & undetected & $15-20$ & wax \\
Decyl $(1-\alpha$-methyl)glucuronate 3e & undetected & $0.5-0.75$ & powder \\
Dodecyl $(1-\alpha$-methyl)glucuronate 3f & $22 \pm 0.2$ & $0.03-0.05$ & powder \\
Octyl $(1-\beta$-methyl)galacturonate 5 & $31 \pm 0.9$ & insoluble at $\approx 25^{\circ} \mathrm{C} ;>100$ at T $>$ Tk & powder \\
Octyl $(1-\alpha$-methyl)mannuronate 7 & undetected & $5.0-6.2$ & oil \\
\hline
\end{tabular}

${ }^{\mathrm{a}}$ Krafft Temperature.

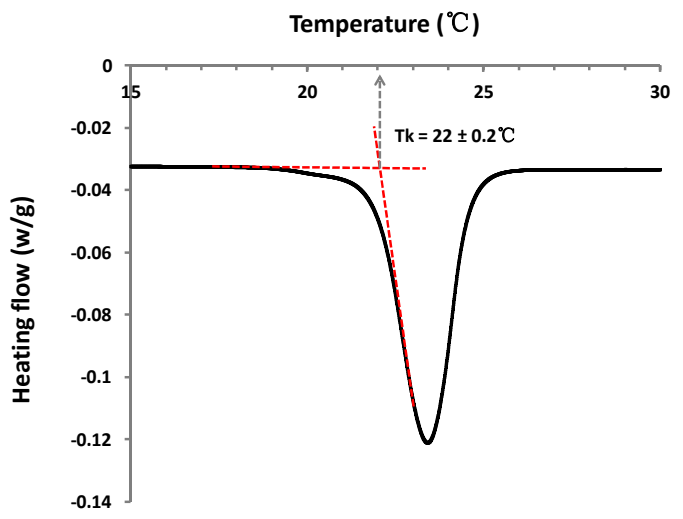

(A)

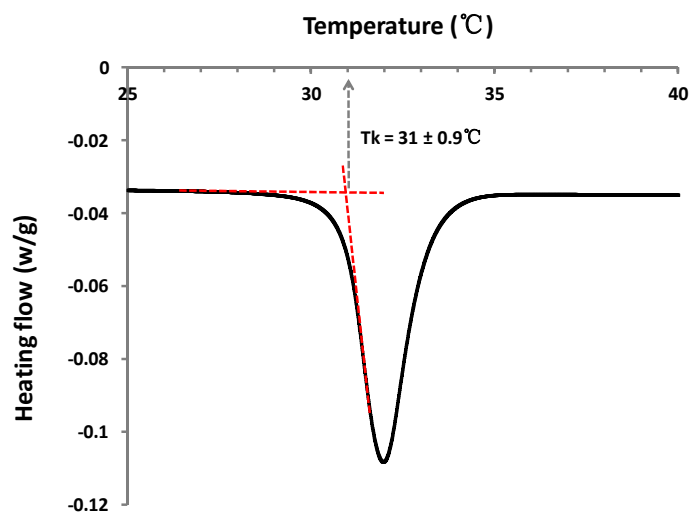

(B)

Figure 4. Representative DSC curves of phase transition for hydrated (A) dodecyl (1- $\alpha$-methyl) glucuronate $3 \mathbf{f}$ and $(\mathbf{B})$ octyl (1- $\beta$-methyl)galacturonate 5 .

Firstly, the role of the hydrophobic tail length on the solubility of the molecules was investigated. For the alkyl (1- $\alpha$-methyl)glucuronate series, with a gradual increase of hydrophobic chain length, hexyl and octyl (1- $\alpha$-methyl)glucuronates ( $3 \mathbf{c}$ and $3 \mathbf{d}$ respectively) appear more wax-like, while the decyl and dodecyl derivatives ( $3 \mathbf{e}$ and $\mathbf{3 f}$ respectively) are both solid powders. Results suggest that as the chain length increases, the phase structure becomes more condensed. Regarding solubility, DSC results indicate that only dodecyl (1- $\alpha$-methyl)glucuronate $3 \mathrm{f}$ is characterized by a low Tk, at $22 \pm 0.2{ }^{\circ} \mathrm{C}$, near room temperature. DSC curves of other alkyl (1- $\alpha$-methyl)glucuronates $(3 \mathbf{c}-3 \mathbf{e})$ are characterized by a straight line without any detected signal (not shown) between $4{ }^{\circ} \mathrm{C}$ and $65^{\circ} \mathrm{C}$. In addition, visual observations show that the concentration limit of apparently clear solutions for each molecule decreases as the chain length increases, from $50 \mathrm{mM}$ for hexyl (1- $\alpha$-methyl)glucuronate $3 \mathrm{c}$ to $0.03 \mathrm{mM}$ for the dodecyl derivative $3 \mathrm{f}$. It is important to note that the limit of limpid aqueous solutions have been observed at room temperature of about $25^{\circ} \mathrm{C}$, above the Tk of each alkyl (1- $\alpha$-methyl)glucuronate studied here. Above this limit, solutions are turbid, and remain as such even when heating solutions up to $50^{\circ} \mathrm{C}$. A complete study of the phase diagram would be necessary to describe the evolution of the structures formed as a function of concentration and temperature. 
Abel et al. indicated that the solubility of sugar surfactants like dodecyl $\beta$-maltoside was defined by the stability of their crystal structures at a molecular level [25]. In accordance with this tendency, the results reveal that, for the alkyl (1- $\alpha$-methyl)glucuronate series, the longer the alkyl chain is, the less soluble the molecule is, due to a more stable crystal structure (solid instead of wax).

Zhang et al. revealed that the nature of the sugar head plays an important role as to form a hydrogen bond network with water molecules to promote the dissolution of sugar-based surfactants in water [26]. In our study, for the octyl (1- $\alpha$-methyl)uronates with variable sugar head, octyl (1- $\alpha$-methyl)mannuronate 7 appears oily, contrary to the wax-like glucuronate derivative $3 \mathbf{d}$. Moreover, DSC curves of both molecules show no signal corresponding to the Tk detection. However, observations indicate that clear solutions of octyl (1- $\alpha$-methyl)mannuronate 7 are obtained for concentrations up to $5 \mathrm{mM}$, slightly lower than for glucuronate derivative $3 \mathbf{d}(20 \mathrm{mM})$. Concentrated solutions of compound 7 above this limit remain turbid even when heated. Considering an identical chain length, the mannose sugar head seems to have a more limited extent of water solubility in comparison to the glucose sugar head.

In the case of molecules in the $\beta$ configuration, observations indicate that octyl (1- $\beta$-methyl) galacturonate 5 is also in a powder state and crystallized very easily during its purification process. DSC results reveal a Tk well above room temperature, at $31 \pm 0.9^{\circ} \mathrm{C}$. Thus, observations show logically that this molecule, which is insoluble at room temperature (at about $25^{\circ} \mathrm{C}$, below Tk), is characterized by a large solubility $(>100 \mathrm{mM})$ above $31^{\circ} \mathrm{C}$. In this case, the solubility increases considerably during the heating process. By applying a natural cooling of the concentrated solutions until room temperature, hydrated crystals are found to precipitate over time, and dispersions become clear again if they are reheated. A reversible solubilization-crystallization transition of octyl (1- $\beta$-methyl)galacturonate hydrated crystals is, therefore, observed. Compared to other alkyl $\alpha$-uronates, due to the Krafft temperature of $31^{\circ} \mathrm{C}$, the solubility of the galacturonate derivative 5 is much more limited at room temperature. Above the Krafft point, the extent of aqueous solubility of compound 5 becomes much larger than other alkyl (1- $\alpha$-methyl)uronates.

These various types of behavior were also observed for glucose-based surfactants by Boyd et al [27]. The authors indicated that, for high concentrations (above CMC) of alkyl polyglycosides, the concentration limit to obtain an apparently clear solution reflects a phase transition. Depending on the considered molecule, the boundary could correspond to the evolution from soluble micelles to other phase structures, and turbid solutions obtained could be constituted of insoluble phases, as hexagonal or lamellar dispersions, in equilibrium with or without micelles.

To sum up, the aqueous solubility of this new series of sugar esters depends on the alkyl chain length, the configuration, and the nature of the sugar head. It is important to note that these factors can either cooperate or compete with each other, which makes the aqueous solubility behavior more complicated and unpredictable for specific molecules.

\subsection{Surface Activity}

For each molecule, parameters related to the surface tension measurement are given in Table 2. The estimated standard deviations, regarding the graphic determination of the parameters, are also reported.

Table 2. Physical parameters of surface activity for investigated molecules.

\begin{tabular}{cccccc}
\hline Molecule & $\mathbf{C M C}(\mathbf{m M})$ & {$[\mathbf{C}]_{\max }(\mathbf{m M})$} & $\begin{array}{c}\gamma_{\mathbf{c m c}} \\
\left(\mathbf{m N} \cdot \mathbf{m}^{-1}\right)\end{array}$ & $\begin{array}{c}\mathbf{A}_{\min } \\
\left(\AA^{2} / \mathbf{m o l e c u l e}\right)\end{array}$ & $\mathbf{T}\left({ }^{\circ} \mathbf{C}\right)$ \\
\hline Hexyl (1- $\alpha$-methyl)glucuronate 3c & $55 \pm 5$ & $50-60$ & $30.8 \pm 0.8$ & $39.2 \pm 2.9$ & 25 \\
Octyl (1- $\alpha$-methyl)glucuronate 3d & $6.0 \pm 0.5$ & $15-20$ & $29.2 \pm 0.4$ & $41.0 \pm 1$ & 25 \\
Decyl (1- $\alpha$-methyl)glucuronate 3e & $0.65 \pm 0.05$ & $0.5-0.75$ & $28.1 \pm 0.1$ & $42.4 \pm 2$ & 25 \\
Dodecyl (1- $\alpha$-methyl)glucuronate 3f & $0.056 \pm 0.004$ & $0.03-0.05$ & $28.3 \pm 0.3$ & $45.6 \pm 5$ & 25 \\
Octyl (1- $\beta$-methyl)galacturonate 5 & $6.9 \pm 0.4$ & $>100$ & $29.4 \pm 0.4$ & $42.9 \pm 3.9$ & 40 \\
Octyl (1- $\alpha$-methyl)mannuronate 7 & $5.5 \pm 0.5$ & $5.0-6.2$ & $28.3 \pm 0.3$ & $42.8 \pm 2$ & 25 \\
\hline
\end{tabular}


In all cases, the results reveal expected surfactant behavior, with a decrease of surface tension which becomes constant after a critical concentration is reached, i.e., the CMC. The corresponding curves of surface tension vs. concentration are displayed on Figure 5, at a controlled temperature of $25{ }^{\circ} \mathrm{C}$, except for galacturonate derivative 5 at $50{ }^{\circ} \mathrm{C}$, in accordance with the Tk value of $31 \pm 0.9^{\circ} \mathrm{C}$. CMC, $\gamma_{\mathrm{cmc}}$, and $\mathrm{A}_{\mathrm{min}}$ were deduced from these surface tension curves. The concentration limit of apparently clear solutions was also reported at $25{ }^{\circ} \mathrm{C}$ or $50{ }^{\circ} \mathrm{C}$ depending on $\mathrm{Tk}$. In regards to calculated $\mathrm{A}_{\min }$, results do not reveal a significant difference, $\mathrm{A}_{\min }$ varying between $39.2 \pm 2.9 \AA^{2} /$ molecule and $45.6 \pm 5 \AA^{2} /$ molecule, whatever the alkyl chain length, the configuration, and the nature of the sugar head.

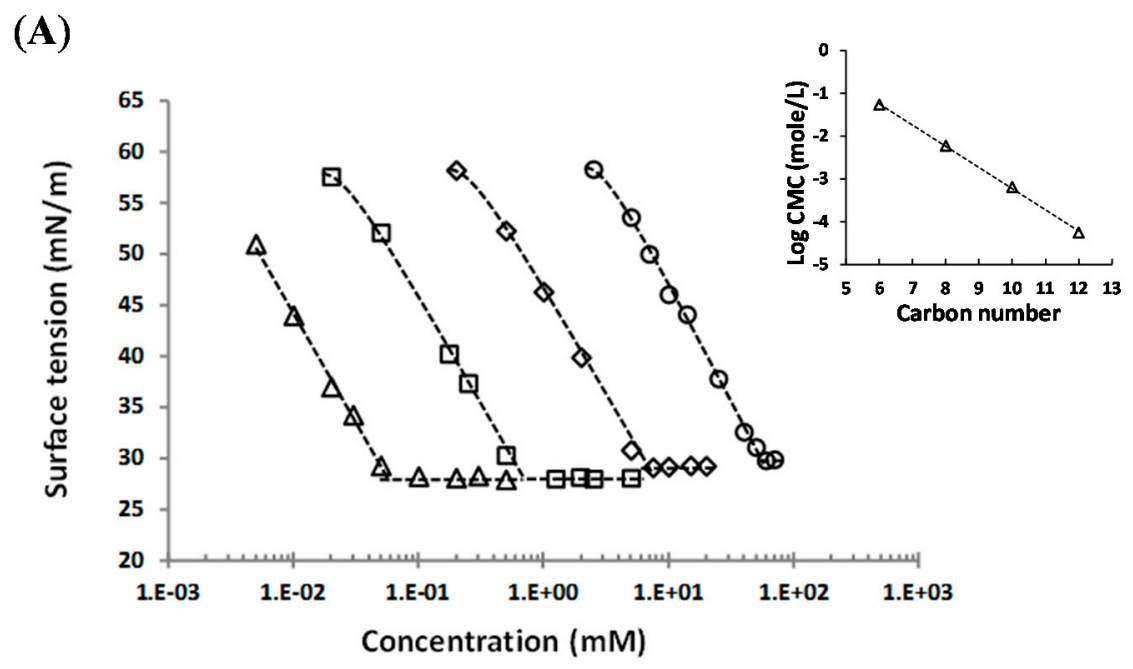

(B)

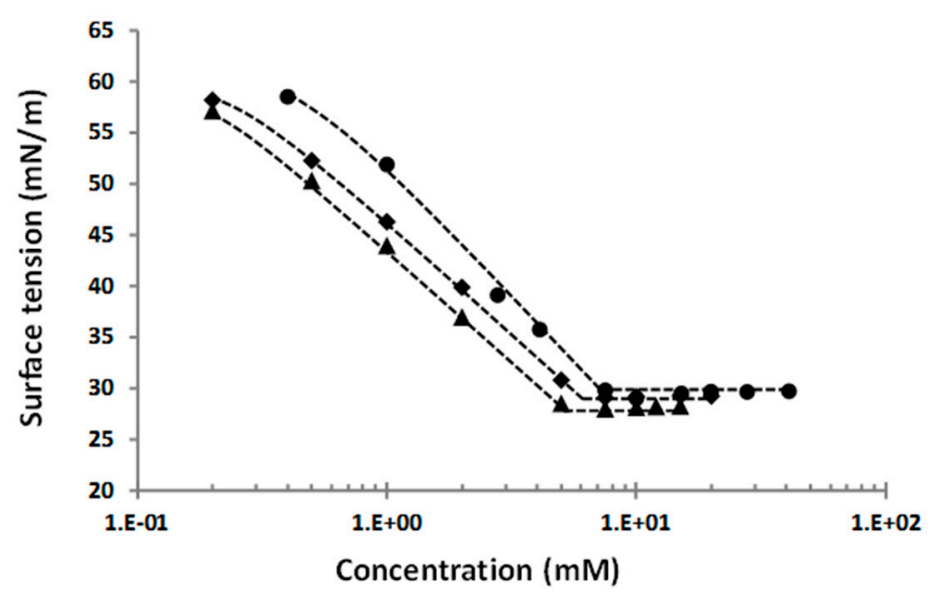

Figure 5. Representative curves of surface tension vs. molecule concentration for: (A) alkyl (1- $\alpha$-methyl) glucuronate in water at $25^{\circ} \mathrm{C}$ depending on chain length, $\bigcirc-C_{6}(3 \mathbf{c}), \diamond-C_{8}$ (3d), $\square-C_{10}$ (3e), $\triangle-\mathrm{C}_{12}$ (3f), and (B) octyl esters derived from different sugars, $\bullet$ - octyl (1- $\beta$-methyl)galacturonate 5 at $40{ }^{\circ} \mathrm{C}, \boldsymbol{\Delta}$-octyl (1- $\alpha$-methyl)glucuronate $3 \mathrm{~d}$ at $25{ }^{\circ} \mathrm{C}, \boldsymbol{\Delta}$-octyl (1- $\alpha$-methyl)mannuronate 7 at $25{ }^{\circ} \mathrm{C}$. Insert: variation of Log CMC with the carbon numbers of the alkyl chain for alkyl (1- $\alpha$-methyl)glucuronate at $25^{\circ} \mathrm{C}$. ( - guide line $)$.

First, the alkyl chain lengh effect of alkyl (1- $\alpha$-methyl)glucuronates on surface activity are discussed. Surface tension curves reveal that the CMC value decreases almost one decade with the increasing chain length of two carbons, from $55 \pm 5 \mathrm{mM}$ for the hexyl derivative $3 \mathrm{c}$ to $0.056 \pm 0.004 \mathrm{mM}$ for the dodecyl derivative $3 f$. Indeed, results show a linear relationship between the alkyl chain length 
and the Log CMC for alkyl (1- $\alpha$-methyl)glucuronates at $25^{\circ} \mathrm{C}$ (insert of Figure 5), which obeys the empirical equation used for surfactants [28-30]:

$$
\log \mathrm{CMC}=\mathrm{A}-\mathrm{Bn}
$$

where $\mathrm{n}$ is the carbon numbers or the length of the alkyl chain; and A and B are empirical constants. The literature reported a rangeof values of $B$ between 0.3 and $0.5[28,29]$ with, generally, a value of $B$ close to 0.3 for ionic surfactants, and close to 0.5 for non-ionic surfactants, according Rosen et al. [30]. For our synthesized alkyl $\alpha$-glucuronates, the calculated values of $\mathrm{A}$ is 1.7 and $\mathrm{B}$ is 0.5 , in agreement with the litterature for non-ionic surfactants.

In addition, results show a weak dependence of $\gamma_{\mathrm{cmc}}$ on the alkyl chain length: $\gamma_{\mathrm{cmc}}$ seems to slightly decrease when the number of carbon atoms increases, from $30.8 \pm 0.8 \mathrm{mN} / \mathrm{m}$ for the hexyl $\alpha$-glucuronate derivative $3 \mathrm{c}$ to $28.3 \pm 0.3 \mathrm{mN} / \mathrm{m}$ for the dodecyl $\alpha$ glucuronate derivative $3 \mathrm{f}$.

By comparing the surface activity of three octyl (1-methyl)uronates ( $\alpha$-glucuronate $3 \mathbf{d}$, $\beta$-galacturonate 5, and $\alpha$-mannuronate 7 ), results indicate that values of $C M C, \gamma_{\mathrm{cmc}}$, and $A_{\min }$ are similar with the same order of magnitude: $\mathrm{CMC}$ is in the range $5.5-6.9 \mathrm{mM}, \gamma_{\mathrm{cmc}}$ is in the range 28.3-29.4 mN/m, and $A_{\min }$ is around 41-42.9 $\AA^{2} /$ molecule. However, octyl (1- $\alpha$-methyl)mannuronate 7 appears to be the most efficient with the lowest CMC $(5.5 \pm 0.5 \mathrm{mM})$ and $\gamma_{\mathrm{cmc}}(28.3 \pm 0.3 \mathrm{mN} / \mathrm{m})$ values, while octyl (1- $\beta$-methyl)galacturonate 5 is characterized by the highest CMC $(6.9 \pm 0.4 \mathrm{mM})$ and $\gamma_{\mathrm{cmc}}(29.4 \pm 0.36 \mathrm{mN} / \mathrm{m})$. Schmidt-Lassen et al. studied the CMC of pure sugar-based non-ionic surfactants and suggested that the CMC of octyl $\alpha$-mannoside $(10.9 \mathrm{mM})$ was comparable to the CMC of octyl $\alpha$-glucoside, and smaller than the CMC of octyl $\beta$-galactoside $(31.7 \mathrm{mM})$ [31]. Our results are in agreement with this tendency, and this series of octyl (1-methyl)uronates is characterized by lower $\mathrm{CMC}$ values than corresponding octyl glycosides. Moreover, the measured CMCs of the proposed molecules are much lower than the CMCs of most common ionic surfactants, like SDS (sodium dodecyl sulfate) (7.5 Mm-9.97 mM) [32]. Measured CMCs for decyl and dodecyl (1- $\alpha$-methyl)glucuronates (3e and $\mathbf{3 f}$, respectively) are in the same order of magnitude than common polyoxyethylene (POE)-type non-ionic surfactants. For instance, the CMC was reported to be $0.03-0.09 \mathrm{mM}$ for polyoxyethylene (23) lauryl ether (Brij 35), 0.23-0.24 mM for polyethylene glycol tert-octylphenyl ether (Triton X-100), and 0.050-0.059 mM for polyoxyethylene sorbitan monolaurate (Tween 20) [18,33-35].

In short, all of the proposed alkyl sugar esters, even for shorter alkyl chain $(n=6)$, demonstrate an excellent capability to reduce the surface tension of pure water to a great extent, in accordance with their amphiphilic structures. Results indicate that the surface activity depends mainly on the alkyl chain length and seems to be less influenced by the conformation of the sugar head.

By comparing the $C M C$ values with the solubility limit $[C]_{\max }$ up to which a clear solution was observed, results reveal that only octyl $\beta$-galacturonate derivative 5 has a CMC value much lower than $[C]_{\max }$, highlighting a good property to form micelles, wanted for detergency applications and solubilization processes. In the case of alkyl (1- $\alpha$-methyl)glucuronates, measurements indicate that only octyl derivative $3 \mathbf{d}$ has a CMC value slightly lower than $[\mathrm{C}]_{\max }$, while hexyl, decyl, and dodecyl derivatives (3c, $\mathbf{3 e}$ and $\mathbf{3 f}$ respectively) have a $\mathrm{CMC}$ in the range of $[\mathrm{C}]_{\max }$ values, or $\mathrm{CMC}$ value slightly higher than $[C]_{\max }$, considering the standard deviation. In the same way, results show that octyl (1- $\alpha$-methyl)mannuronate 7 has a CMC value in the range of $[C]_{\max }$ values. This behavior implies that, above $[\mathrm{C}]_{\max }$, multiple non-miscible phases, including soluble micelles or not, and dispersion of structures, such as hexagonal or lamellar phases, could co-exist [27]. These results suggest that the observed change of slope in the surface tension curve may reveal a phase transition rather than a CMC. Direct methods, like solubilization of hydrophobic dyes detected by colorimetric analysis and small-angle scattering or dynamic light scattering experiments, should be used to evidence the presence of the micellar phase and confirm the CMC values. Therefore, this series of sugar esters appears to have a complicated phase diagram. As mentioned before, this complex solubility behavior was also observed for alkylpolyglucoside surfactants by Boyd et al. [27] and more recently on sugar-based surfactants with an alkyl or acyl chain grafted to a glucose or maltose head group by Lu et al. [36]. 
Obviously, a complete phase diagram should be investigated in further studies to understand and characterize the dissolution behavior and the solubility limit of each molecule.

To sum up, except for octyl (1- $\alpha$-methyl)glucuronate $3 \mathbf{d}$ and octyl (1- $\beta$-methyl)galacturonate 5 , these results suggest a moderate ability of these alkyl sugar esters to form micelles, due to an area of limpid solution restricted and close to the CMC.

\section{Materials and Methods}

\subsection{General Methods}

All chemicals were purchased from Fisher Scientific (Illkirch, France), and Sigma Aldrich (St Quentin Fallavier, France) and used as received. Optical rotations were measured with a Perkin-Elmer Model 343 polarimeter (Perkin-Elmer Instruments, Courtaboeuf, France) using a sodium lamp at $20^{\circ} \mathrm{C}$. Optical rotation $\left([\alpha]_{\mathrm{D}}\right)$ values are given in $10^{-1} \mathrm{deg} \mathrm{cm}^{2} \mathrm{~g}^{-1}$ and concentrations (c) are given in $\mathrm{g}$ for $100 \mathrm{~mL}$. Mass analyses were performed on a Waters spectrometer (SINAPT TG2SI, Manchester, UK) using electrospray ionization (Z-Spray). NMR analysis were performed on a BRUKER DRX spectrometer (Bruker, Wissembourg, France) operating at $600 \mathrm{MHz}$ for proton ${ }^{1} \mathrm{H}$ and $151 \mathrm{MHz}$ for ${ }^{13} \mathrm{C}$ atoms or a spectrometer Bruker (Bruker) operating at $400 \mathrm{MHz}$ for ${ }^{1} \mathrm{H}$ and $100 \mathrm{MHz}$ for ${ }^{13} \mathrm{C}$. Samples of oxidized products were prepared in deuterium oxide while samples of esters were dissolved in MeOD- $d_{4}$.

\subsection{General Procedure for the Oxidation}

Methyl glycoside (methyl $\alpha$-D-glucopyranoside, methyl $\beta$-D-galactopyranoside, or methyl $\alpha$-D-mannopyranoside) (4-15 g) was firstly dissolved in deionized water $(10 \mathrm{~mL} / \mathrm{g})$ and acetonitrile $(10 \mathrm{~mL} / \mathrm{g})$ was added. TEMPO (0.3 eq.), BAIB (2.2 eq.), and $\mathrm{NaHCO}_{3}$ (1 eq.) were subsequently added and the mixture was stirred at $0{ }^{\circ} \mathrm{C}$ for $2 \mathrm{~h}$ and at room temperature. The reaction was monitored by TLC. After completion, the reaction was quenched by the addition of ethanol, followed by evaporation and decantation with $\mathrm{H}_{2} \mathrm{O}$ /EtOAc. The aqueous phase was concentrated and the resultant syrup was evaporated to dryness overnight to quantitatively give the corresponding sodium uronate as a white crystalline solid. For methyl $\alpha$-D-glucopyranoside, the reaction was finished after $15 \mathrm{~h}$; for the methyl $\beta$-D-galactopyranoside, a second addition of TEMPO (0.3 eq.) and BAIB (2.2 eq.) was necessary and the reaction was finished after $48 \mathrm{~h}$; for methyl $\alpha$-D-mannopyranoside, two supplementary additions of TEMPO (0.3 eq.) and BAIB (2.2 eq.) and 8 days were necessary to oxidize all of the mannoside.

\subsection{General Procedure for the Esterification}

Sodium 1-methyluronate $(5 \mathrm{~g})$ was added to the desired fatty alcohol $(100 \mathrm{~mL})$ and a suspension was obtained. Sodium sulfate $(5 \mathrm{~g})$ and a catalytic amount of concentrated $\mathrm{H}_{2} \mathrm{SO}_{4}(0.9 \mathrm{~mL})$ were successively added and the mixture was stirred at $65{ }^{\circ} \mathrm{C}$. The reaction was monitored by TLC. After completion $(\sim 24 \mathrm{~h})$, the mixture was neutralized with triethylamine until $\mathrm{pH} \sim 7$, filtered, and evaporated. The crude was purified by flash column chromatography to give the corresponding ester. When using octanol, decanol, and dodecanol, the excess of alcohol was firstly removed using cyclohexane, then $\mathrm{CH}_{2} \mathrm{Cl}_{2} / \mathrm{MeOH}$ eluent (from 100/0 to 93/7) was used.

\subsection{Compound Characterization Data}

All the NMR spectra are available in the Supplementary Materials.

Sodium (methyl $\alpha$-D-glucopyranosid)uronate 2. White powder. Quantitative yield from methyl $\alpha$-D-glucopyranoside. $[\alpha]_{D}^{20}=+103^{\circ}\left(c 0.1 ; \mathrm{H}_{2} \mathrm{O}\right) ;{ }^{1} \mathrm{H}-\mathrm{NMR}\left(400 \mathrm{MHz}, \mathrm{D}_{2} \mathrm{O}\right) \delta 4.83(1 \mathrm{H}, \mathrm{d}, \mathrm{H}-1$, $\left.J_{1,2}=3.7 \mathrm{~Hz}\right), 3.90\left(1 \mathrm{H}, \mathrm{d}, \mathrm{H}-5, J_{4,5}=10.0 \mathrm{~Hz}\right), 3.69\left(1 \mathrm{H}, \mathrm{dd}, \mathrm{H}-3, J_{2,3}=9.8 \mathrm{~Hz}, J_{3,4}=8.9 \mathrm{~Hz}\right), 3.61(1 \mathrm{H}$, $\left.\mathrm{dd}, \mathrm{H}-2, J_{2,3}=9.7 \mathrm{~Hz}, J_{1,2}=3.7 \mathrm{~Hz}\right), 3.51\left(1 \mathrm{H}, \mathrm{dd}, \mathrm{H}-4, J_{4,5}=10.0 \mathrm{~Hz}, J_{3,4}=8.9 \mathrm{~Hz}\right), 3.43\left(3 \mathrm{H}, \mathrm{s},-\mathrm{O}-\mathrm{CH}_{3}\right)$. ${ }^{13} \mathrm{C}-\mathrm{NMR}\left(101 \mathrm{MHz}, \mathrm{D}_{2} \mathrm{O}\right) \delta 176.6$ (C=O), 99.3 (C-1), 72.8 (C-3), 71.9 (C-4, C-5), 71.0 (C-2), $55.1\left(-\mathrm{O}_{-} \mathrm{CH}_{3}\right)$. HRMS (ESI) $m / z$ calcd for $\mathrm{C}_{7} \mathrm{H}_{12} \mathrm{O}_{7} \mathrm{Na}[\mathrm{M}-\mathrm{Na}]^{+} 231.0481$, found 231.0489. 
Ethyl (methyl $\alpha$-D-glucopyranosid)uronate 3a. Colorless syrup. Yield 58\% from sodium (methyl $\alpha$-Dglucopyranosid)uronate using the general procedure. $R_{\mathrm{f}}=0.21\left(\mathrm{CH}_{2} \mathrm{Cl}_{2} / \mathrm{MeOH}=93: 7\right) ;[\alpha]_{D}^{20}=+137^{\circ}$ (c 0.1; MeOH); ${ }^{1} \mathrm{H}-\mathrm{NMR}\left(400 \mathrm{MHz}, \mathrm{MeOD}-d_{4}\right) \delta 4.70\left(1 \mathrm{H}, \mathrm{d}, \mathrm{H}-1, J_{1,2}=3.7 \mathrm{~Hz}\right), 4.22\left(2 \mathrm{H}, \mathrm{q},-\mathrm{O}_{-} \mathrm{CH}_{2}-\right.$, $J=7.1 \mathrm{~Hz}), 4.00\left(1 \mathrm{H}, \mathrm{d}, \mathrm{H}-5, J_{4,5}=9.8 \mathrm{~Hz}\right), 3.61\left(1 \mathrm{H}, \mathrm{t}, \mathrm{H}-3, J_{2,3}=J_{3,4}=9.2 \mathrm{~Hz}\right), 3.52(1 \mathrm{H}, \mathrm{dd}, \mathrm{H}-4$, $\left.J_{4,5}=9.8 \mathrm{~Hz}, J_{3,4}=9.2 \mathrm{~Hz}\right), 3.43\left(4 \mathrm{H}, \mathrm{m}, \mathrm{H}-2,-\mathrm{O}-\mathrm{CH}_{3}\right), 1.29\left(3 \mathrm{H}, \mathrm{t},-\mathrm{CH}_{2}-\mathrm{CH}_{3}, J=7.1 \mathrm{~Hz}\right) .{ }^{13} \mathrm{C}-\mathrm{NMR}(101$ $\left.\mathrm{MHz}, \mathrm{MeOD}-d_{4}\right) \delta 171.5$ (C=O), 101.9 (C-1), 74.5 (C-3), 73.3 (C-2), 73.1 (C-4), 72.9 (C-5), 62.5 (-O-CH - -, $56.0\left(-\mathrm{O}-\mathrm{CH}_{3}\right), 14.4\left(-\mathrm{CH}_{3}\right)$. HRMS (ESI) $m / z$ cald for $\mathrm{C}_{9} \mathrm{H}_{16} \mathrm{O}_{7} \mathrm{Na}[\mathrm{M}+\mathrm{Na}]^{+} 259.0794$, found 259.0798 .

Butyl (methyl $\alpha$-D-glucopyranosid)uronate $3 \mathbf{b}$. White powder. Yield $72 \%$ from sodium (methyl $\alpha$-Dglucopyranosid)uronate using the general procedure. $R_{\mathrm{f}}=0.28(\mathrm{EtOAc}) ;[\alpha]_{D}^{20}=+121^{\circ}(c 0.1 ; \mathrm{MeOH})$; ${ }^{1} \mathrm{H}-\mathrm{NMR}\left(400 \mathrm{MHz}, \mathrm{MeOD}-d_{4}\right) \delta 4.71\left(1 \mathrm{H}, \mathrm{d}, \mathrm{H}-1, J_{1,2}=3.7 \mathrm{~Hz}\right), 4.19\left(2 \mathrm{H}, \mathrm{t},-\mathrm{O}-\mathrm{CH}_{2}-, J=6.6 \mathrm{~Hz}\right), 4.01$ $\left(1 \mathrm{H}, \mathrm{dd}, \mathrm{H}-5, J_{4,5}=9.8 \mathrm{~Hz}, J=0.4 \mathrm{~Hz}\right), 3.62\left(1 \mathrm{H}, \mathrm{t}, \mathrm{H}-3, J_{2,3}=J_{3,4}=9.2 \mathrm{~Hz}\right), 3.53\left(1 \mathrm{H}, \mathrm{dd}, \mathrm{H}-4, J_{4,5}=9.8 \mathrm{~Hz}\right.$, $\left.J_{3,4}=9.2 \mathrm{~Hz}\right), 3.42\left(4 \mathrm{H}, \mathrm{m}, \mathrm{H}-2,-\mathrm{O}-\mathrm{CH}_{3}\right), 1.66\left(2 \mathrm{H}, \mathrm{m},-\mathrm{O}-\mathrm{CH}_{2}-\mathrm{CH}_{2}-\right), 1.42\left(2 \mathrm{H}, \mathrm{m},-\mathrm{CH}_{2}-\mathrm{CH}_{3}\right), 0.96(3 \mathrm{H}$, $\left.\mathrm{t},-\mathrm{CH}_{2}-\mathrm{CH}_{3}, J=7.4 \mathrm{~Hz}\right) .{ }^{13} \mathrm{C}-\mathrm{NMR}\left(101 \mathrm{MHz}, \mathrm{MeOD}-d_{4}\right) \delta 171.6(\mathrm{C}=\mathrm{O}), 101.9$ (C-1), 74.6 (C-3), 73.3 (C-2), $73.1(\mathrm{C}-4), 72.9$ (C-5), $66.2\left(-\mathrm{O}-\mathrm{CH}_{2}-\right), 56.0\left(-\mathrm{O}-\mathrm{CH}_{3}\right), 31.7\left(-\mathrm{O}-\mathrm{CH}_{2}-\mathrm{CH}_{2}-\right), 20.1\left(-\mathrm{CH}_{2}-\mathrm{CH}_{3}\right), 14.0$ $\left(-\mathrm{CH}_{3}\right)$. HRMS (ESI) $m / z$ cald for $\mathrm{C}_{11} \mathrm{H}_{20} \mathrm{O}_{7} \mathrm{Na}[\mathrm{M}+\mathrm{Na}]^{+}$287.1107, found 287.1118.

Hexyl (methyl $\alpha$-D-glucopyranosid)uronate 3c. Colorless syrup. Yield 59\% from sodium (methyl $\alpha$-Dglucopyranosid)uronate using the general procedure. $R_{\mathrm{f}}=0.23\left(\mathrm{CH}_{2} \mathrm{Cl}_{2} / \mathrm{MeOH}=93: 7\right) ;[\alpha]_{D}^{20}=+103^{\circ}$ (c 0.1; MeOH); ${ }^{1} \mathrm{H}-\mathrm{NMR}\left(400 \mathrm{MHz}, \mathrm{MeOD}-d_{4}\right) \delta 4.71\left(1 \mathrm{H}, \mathrm{d}, \mathrm{H}-1, J_{1,2}=3.7 \mathrm{~Hz}\right), 4.18\left(2 \mathrm{H}, \mathrm{t},-\mathrm{O}-\mathrm{CH}_{2}-\right.$, $J=6.6 \mathrm{~Hz}), 4.01\left(1 \mathrm{H}, \mathrm{d}, \mathrm{H}-5, J_{4,5}=9.8 \mathrm{~Hz}\right), 3.62\left(1 \mathrm{H}, \mathrm{t}, \mathrm{H}-3, J_{2,3}=J_{3,4}=9.2 \mathrm{~Hz}\right), 3.53(1 \mathrm{H}, \mathrm{dd}, \mathrm{H}-4$, $\left.J_{4,5}=9.8 \mathrm{~Hz}, J_{3,4}=9.2 \mathrm{~Hz}\right), 3.45\left(4 \mathrm{H}, \mathrm{m}, \mathrm{H}-2,-\mathrm{O}-\mathrm{CH}_{3}\right), 1.68\left(2 \mathrm{H}, \mathrm{p},-\mathrm{O}-\mathrm{CH}_{2}-\mathrm{CH}_{2}-, J=6.7 \mathrm{~Hz}\right), 1.36$ $\left(6 \mathrm{H}, \mathrm{m},-\left(\mathrm{CH}_{2}\right)_{3}-\mathrm{CH}_{3}\right), 0.91\left(3 \mathrm{H}, \mathrm{t},-\mathrm{CH}_{2}-\mathrm{CH}_{3}, J=6.9 \mathrm{~Hz}\right) .{ }^{13} \mathrm{C}-\mathrm{NMR}\left(101 \mathrm{MHz}, \mathrm{MeOD}-d_{4}\right) \delta 171.6$

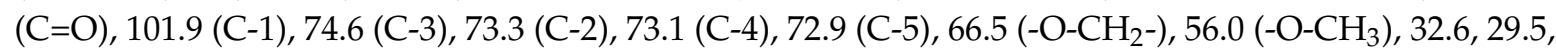
26.6, $23.6\left(-\mathrm{O}-\mathrm{CH}_{2}-\left(\mathrm{CH}_{2}\right)_{4}-\mathrm{CH}_{3}\right), 14.3\left(-\mathrm{CH}_{3}\right)$. HRMS (ESI) $m / z$ cald for $\mathrm{C}_{13} \mathrm{H}_{25} \mathrm{O}_{7}[\mathrm{M}+\mathrm{H}]^{+} 293.1600$, found 293.1608 .

Octyl (methyl $\alpha$-D-glucopyranosid)uronate $3 \mathrm{~d}$. White syrup. Yield $57 \%$ from sodium (methyl $\alpha$-Dglucopyranosid)uronate using the general procedure. $R_{\mathrm{f}}=0.24\left(\mathrm{CH}_{2} \mathrm{Cl}_{2} / \mathrm{MeOH}=93: 7\right) ;[\alpha]_{D}^{20}=+99^{\circ}$ (c $0.1 ; \mathrm{MeOH}) ;{ }^{1} \mathrm{H}-\mathrm{NMR}\left(400 \mathrm{MHz}, \mathrm{MeOD}-d_{4}\right) \delta 4.71\left(1 \mathrm{H}, \mathrm{d}, \mathrm{H}-1, J_{1,2}=3.7 \mathrm{~Hz}\right), 4.18\left(2 \mathrm{H}, \mathrm{t},-\mathrm{O}-\mathrm{CH}_{2}-\right.$, $J=6.6 \mathrm{~Hz}), 4.01\left(1 \mathrm{H}, \mathrm{d}, \mathrm{H}-5, J_{4,5}=9.8 \mathrm{~Hz}\right), 3.62\left(1 \mathrm{H}, \mathrm{t}, \mathrm{H}-3, J_{2,3}=J_{3,4}=9.2 \mathrm{~Hz}\right), 3.52(1 \mathrm{H}, \mathrm{dd}, \mathrm{H}-4$, $\left.J_{4,5}=9.8 \mathrm{~Hz}, J_{3,4}=9.2 \mathrm{~Hz}\right), 3.45\left(4 \mathrm{H}, \mathrm{m}, \mathrm{H}-2,-\mathrm{O}-\mathrm{CH}_{3}\right), 1.68\left(2 \mathrm{H}, \mathrm{p},-\mathrm{O}-\mathrm{CH}_{2}-\mathrm{CH}_{2^{-}}, J=6.6 \mathrm{~Hz}\right), 1.35(10 \mathrm{H}$, $\left.\mathrm{m},-\left(\mathrm{CH}_{2}\right)_{5}-\mathrm{CH}_{3}\right), 0.91\left(3 \mathrm{H}, \mathrm{t},-\mathrm{CH}_{2}-\mathrm{CH}_{3}, J=6.8 \mathrm{~Hz}\right) .{ }^{13} \mathrm{C}-\mathrm{NMR}\left(101 \mathrm{MHz}, \mathrm{MeOD}-d_{4}\right) \delta 171.6(\mathrm{C}=\mathrm{O})$, 101.9 (C-1), 74.5 (C-3), 73.3 (C-2), 73.1 (C-4), 72.9 (C-5), $66.5\left(-{\left.\mathrm{O}-\mathrm{CH}_{2}-\right)}^{-}, 56.0\left(-\mathrm{O}^{-} \mathrm{CH}_{3}\right), 33.0,30.3,30.3\right.$, $29.9,26.9,23.7\left(-\mathrm{O}-\mathrm{CH}_{2}-\left(\mathrm{CH}_{2}\right)_{6}-\mathrm{CH}_{3}\right), 14.4\left(-\mathrm{CH}_{3}\right)$. HRMS (ESI) $m / z$ cald for $\mathrm{C}_{15} \mathrm{H}_{28} \mathrm{O}_{7} \mathrm{Na}[\mathrm{M}+\mathrm{Na}]^{+}$ 343.1733 , found 343.1744 .

Decyl (methyl $\alpha$-D-glucopyranosid)uronate 3e. White powder. Yield $63 \%$ from sodium (methyl $\alpha$-Dglucopyranosid)uronate using the general procedure. $R_{\mathrm{f}}=0.4(\mathrm{EtOAc} / \mathrm{MeOH}=95: 5) ;[\alpha]_{D}^{20}=+93^{\circ}$ (c $0.1 ; \mathrm{MeOH}) ;{ }^{1} \mathrm{H}-\mathrm{NMR}\left(400 \mathrm{MHz}, \mathrm{MeOD}-d_{4}\right) \delta 4.71\left(1 \mathrm{H}, \mathrm{d}, \mathrm{H}-1, J_{1,2}=3.7 \mathrm{~Hz}\right), 4.18\left(2 \mathrm{H}, \mathrm{t},-\mathrm{O}-\mathrm{CH}_{2}-\right.$, $J=6.6 \mathrm{~Hz}), 4.01\left(1 \mathrm{H}, \mathrm{d}, \mathrm{H}-5, J_{4,5}=9.8 \mathrm{~Hz}\right), 3.62\left(1 \mathrm{H}, \mathrm{t}, \mathrm{H}-3, J_{2,3}=J_{3,4}=9.2 \mathrm{~Hz}\right), 3.52(1 \mathrm{H}, \mathrm{dd}, \mathrm{H}-4$, $\left.J_{4,5}=9.8 \mathrm{~Hz}, J_{3,4}=9.2 \mathrm{~Hz}\right), 3.44\left(4 \mathrm{H}, \mathrm{m}, \mathrm{H}-2,-\mathrm{O}-\mathrm{CH}_{3}\right), 1.68\left(2 \mathrm{H}, \mathrm{p},-\mathrm{O}-\mathrm{CH}_{2}-\mathrm{CH}_{2}-, J=6.6 \mathrm{~Hz}\right), 1.35$ $\left(14 \mathrm{H}, \mathrm{m},-\left(\mathrm{CH}_{2}\right)_{7}-\mathrm{CH}_{3}\right), 0.90\left(3 \mathrm{H}, \mathrm{t},-\mathrm{CH}_{2}-\mathrm{CH}_{3}, J=6.8 \mathrm{~Hz}\right) .{ }^{13} \mathrm{C}-\mathrm{NMR}\left(101 \mathrm{MHz}, \mathrm{MeOD}-d_{4}\right) \delta 171.6$ $(\mathrm{C}=\mathrm{O}), 101.9$ (C-1), 74.5 (C-3), 73.3 (C-2), 73.1 (C-4), 72.9 (C-5), $66.5\left(-\mathrm{O}_{-} \mathrm{CH}_{2}-\right), 56.0\left(-\mathrm{O}^{-} \mathrm{CH}_{3}\right), 33.1,30.7$ (2C), 30.5, 30.4, 29.6, 26.9, $23.7\left(-\mathrm{O}-\mathrm{CH}_{2}-\left(\mathrm{CH}_{2}\right)_{8}-\mathrm{CH}_{3}\right), 14.5\left(-\mathrm{CH}_{3}\right)$. HRMS (ESI) $m / z$ cald $\mathrm{C}_{17} \mathrm{H}_{36} \mathrm{NO}_{7}$ $\left[\mathrm{M}+\mathrm{NH}_{4}\right]^{+} 366.2492$, found 366.2499.

Dodecyl (methyl $\alpha$-D-glucopyranosid)uronate 3 f. White powder. Yield $49 \%$ from sodium (methyl $\alpha$-Dglucopyranosid)uronate using the general procedure. $R_{\mathrm{f}}=0.35$ (EtOAc); $[\alpha]_{D}^{20}=+82^{\circ}(c 0.1 ; \mathrm{MeOH})$; ${ }^{1} \mathrm{H}-\mathrm{NMR}\left(400 \mathrm{MHz}, \mathrm{MeOD}-d_{4}\right) \delta 4.71\left(1 \mathrm{H}, \mathrm{d}, \mathrm{H}-1, J_{1,2}=3.7 \mathrm{~Hz}\right), 4.18\left(2 \mathrm{H}, \mathrm{t},-\mathrm{O}-\mathrm{CH}_{2}-, J=6.6 \mathrm{~Hz}\right)$, $4.01\left(1 \mathrm{H}, \mathrm{d}, \mathrm{H}-5, J_{4,5}=9.8 \mathrm{~Hz}\right), 3.62\left(1 \mathrm{H}, \mathrm{t}, \mathrm{H}-3, J_{2,3}=J_{3,4}=9.2 \mathrm{~Hz}\right), 3.52\left(1 \mathrm{H}, \mathrm{dd}, \mathrm{H}-4, J_{4,5}=9.8 \mathrm{~Hz}\right.$, $\left.J_{3,4}=9.2 \mathrm{~Hz}\right), 3.44\left(4 \mathrm{H}, \mathrm{m}, \mathrm{H}-2,-\mathrm{O}-\mathrm{CH}_{3}\right), 1.68\left(2 \mathrm{H}, \mathrm{p},-\mathrm{O}-\mathrm{CH}_{2}-\mathrm{CH}_{2}-, J=6.6 \mathrm{~Hz}\right), 1.32(18 \mathrm{H}, \mathrm{m}$, $\left.-\left(\mathrm{C}_{2}\right)_{9}-\mathrm{CH}_{3}\right), 0.89\left(3 \mathrm{H}, \mathrm{t},-\mathrm{CH}_{2}-\mathrm{CH}_{3}, J=6.8 \mathrm{~Hz}\right) .{ }^{13} \mathrm{C}-\mathrm{NMR}\left(101 \mathrm{MHz}, \mathrm{MeOD}-d_{4}\right) \delta 171.6(\mathrm{C}=\mathrm{O}), 101.9$ 
(C-1), 74.6 (C-3), 73.3 (C-2), 73.1 (C-4), 72.9 (C-5), $66.5\left(-\mathrm{O}^{-} \mathrm{CH}_{2}-\right), 56.0\left(-\mathrm{O}-\mathrm{CH}_{3}\right), 33.1,30.8,30.8,30.7$, 30.7, 30.5, 30.4, 29.6, 26.9, $23.8\left(-\mathrm{O}-\mathrm{CH}_{2}-\left(\mathrm{CH}_{2}\right)_{8}-\mathrm{CH}_{3}\right), 14.5\left(-\mathrm{CH}_{3}\right)$. HRMS (ESI) $m / z$ cald $\mathrm{C}_{19} \mathrm{H}_{36} \mathrm{O}_{7} \mathrm{Na}$ $[\mathrm{M}+\mathrm{Na}]^{+} 399.2359$, found 399.2368 .

Sodium (methyl $\beta$-D-galactopyranosid)uronate 4 . White powder. Quantitative yield from methyl $\beta$-Dgalactopyranoside. $[\alpha]_{D}^{20}=-37^{\circ}\left(c 0.1 ; \mathrm{H}_{2} \mathrm{O}\right) ;{ }^{1} \mathrm{H}-\mathrm{NMR}\left(400 \mathrm{MHz}, \mathrm{D}_{2} \mathrm{O}\right) \delta 4.27\left(1 \mathrm{H}, \mathrm{d}, \mathrm{H}-1, J_{1,2}=7.9 \mathrm{~Hz}\right)$, $4.18\left(1 \mathrm{H}, \mathrm{dd}, \mathrm{H}-4, J_{3,4}=3.5 \mathrm{~Hz}, J_{4,5}=1.2 \mathrm{~Hz}\right), 4.01\left(1 \mathrm{H}, \mathrm{d}, \mathrm{H}-5, J_{4,5}=1.3 \mathrm{~Hz}\right), 3.66(1 \mathrm{H}, \mathrm{dd}, \mathrm{H}-3$, $\left.J_{2,3}=9.9 \mathrm{~Hz}, J_{3,4}=3.5 \mathrm{~Hz}\right), 3.56\left(3 \mathrm{H}, \mathrm{s},-\mathrm{O}-\mathrm{CH}_{3}\right), 3.48\left(1 \mathrm{H}, \mathrm{dd}, \mathrm{H}-2, J_{2,3}=9.9 \mathrm{~Hz}, J_{1,2}=7.9 \mathrm{~Hz}\right) .{ }^{13} \mathrm{C}-\mathrm{NMR}$ (101 MHz, $\left.\mathrm{D}_{2} \mathrm{O}\right) \delta 175.0(\mathrm{C}=\mathrm{O}), 103.2(\mathrm{C}-1), 75.4(\mathrm{C}-5), 72.8$ (C-3), $70.3(\mathrm{C}-2), 70.3(\mathrm{C}-4), 57.1\left(-\mathrm{O}^{-} \mathrm{CH}_{3}\right)$. HRMS (ESI) $m / z$ calcd for $\mathrm{C}_{7} \mathrm{H}_{12} \mathrm{O}_{7} \mathrm{Na}[\mathrm{M}+\mathrm{Na}]^{+} 231.0481$, found 231.0488 .

Octyl (methyl $\beta$-D-galactopyranosid)uronate 5 . White powder. Yield $57 \%$ from sodium (methyl $\beta$-Dgalactopyranosid) uronate using the general procedure. $R_{\mathrm{f}}=0.29\left(\mathrm{CH}_{2} \mathrm{Cl}_{2} / \mathrm{MeOH}=93: 7\right) ;[\alpha]_{D}^{20}=-33^{\circ}$ (c 0.1; MeOH); ${ }^{1} \mathrm{H}-\mathrm{NMR}\left(400 \mathrm{MHz}, \mathrm{MeOD}-d_{4}\right) \delta 4.26\left(1 \mathrm{H}, \mathrm{d}, \mathrm{H}-5, J_{4,5}=1.4 \mathrm{~Hz}\right), 4.18(3 \mathrm{H}, \mathrm{m}, \mathrm{H}-1$, $\left.-\mathrm{O}-\mathrm{CH}_{2}-\right), 4.13\left(1 \mathrm{H}, \mathrm{dd}, \mathrm{H}-4, J_{4,5}=1.4 \mathrm{~Hz}, J_{3,4}=2.9 \mathrm{~Hz}\right), 3.54\left(5 \mathrm{H}, \mathrm{m}, \mathrm{H}-2, \mathrm{H}-3,-\mathrm{O}-\mathrm{CH}_{3}\right), 1.68(2 \mathrm{H}, \mathrm{p}$, $\left.-\mathrm{O}-\mathrm{CH}_{2}-\mathrm{CH}_{2}-, J=6.7 \mathrm{~Hz}\right), 1.35\left(10 \mathrm{H}, \mathrm{m},-\left(\mathrm{CH}_{2}\right)_{5}-\mathrm{CH}_{3}\right), 0.9\left(3 \mathrm{H}, \mathrm{m},-\mathrm{CH}_{2}-\mathrm{CH}_{3}, J=6.9 \mathrm{~Hz}\right) .{ }^{13} \mathrm{C}-\mathrm{NMR}$ $\left(101 \mathrm{MHz}, \mathrm{MeOD}-d_{4}\right) \delta 170.3(\mathrm{C}=\mathrm{O}), 105.7$ (C-1), 75.4 (C-5), 74.4 (C-3), 71.8 (C-2), 71.5 (C-4), 66.4 $\left(-\mathrm{O}-\mathrm{CH}_{2}-\right), 57.5\left(-\mathrm{O}-\mathrm{CH}_{3}\right), 33.0,30.3(2 \mathrm{C}), 29.7,27.0,23.7\left(-\mathrm{O}-\mathrm{CH}_{2}-\left(\mathrm{CH}_{2}\right)_{6}-\mathrm{CH}_{3}\right), 14.4\left(-\mathrm{CH}_{3}\right)$. HRMS (ESI) $m / z$ cald for $\mathrm{C}_{15} \mathrm{H}_{29} \mathrm{O}_{7}[\mathrm{M}+\mathrm{H}]^{+} 321.1913$, found 321.1898.

Sodium (methyl $\alpha$-D-mannopyranosid)uronate 6. White powder. Quantitative yield from methyl $\alpha$-D-mannopyranoside. $[\alpha]_{D}^{20}=+40^{\circ}\left(c 1.0 ; \mathrm{H}_{2} \mathrm{O}\right) ;{ }^{1} \mathrm{H}-\mathrm{NMR}\left(400 \mathrm{MHz}, \mathrm{D}_{2} \mathrm{O}\right) \delta 4.77(1 \mathrm{H}, \mathrm{d}, \mathrm{H}-1$, $\left.J_{1,2}=1.9 \mathrm{~Hz}\right), 3.88\left(1 \mathrm{H}, \mathrm{dd}, \mathrm{H}-2, J_{1,2}=1.9 \mathrm{~Hz}, J_{2,3}=3.0 \mathrm{~Hz}\right), 3.86-3.73(3 \mathrm{H}, \mathrm{m}, \mathrm{H}-3, \mathrm{H}-4, \mathrm{H}-5), 3.39(3 \mathrm{H}$, s, -O-CH 3 ). ${ }^{13} \mathrm{C}-\mathrm{NMR}\left(101 \mathrm{MHz}, \mathrm{D}_{2} \mathrm{O}\right) \delta 176.7$ (C=O), 100.8 (C-1), 72.8 (C-5), 70.3 (C-3), 69.7 (C-2), 68.7 (C-4), $54.9\left(-\mathrm{O}-\mathrm{CH}_{3}\right)$. HRMS (ESI) $\mathrm{m} / z$ calcd for $\mathrm{C}_{7} \mathrm{H}_{12} \mathrm{O}_{7} \mathrm{Na}[\mathrm{M}+\mathrm{Na}]^{+} 231.0481$, found 231.0487.

Octyl (methyl $\alpha$-D-mannopyranosid)uronate 7. Yellow syrup. Yield $44 \%$ from sodium (methyl $\alpha$-D-mannopyranosid)uronate using the general procedure. $R_{\mathrm{f}}=0.31\left(\mathrm{CH}_{2} \mathrm{Cl}_{2} / \mathrm{MeOH}=93: 7\right)$; $[\alpha]_{D}^{20}=+58^{\circ}(c 0.1 ; \mathrm{MeOH}) ;{ }^{1} \mathrm{H}-\mathrm{NMR}\left(400 \mathrm{MHz}, \mathrm{MeOD}-d_{4}\right) \delta 4.71\left(1 \mathrm{H}, \mathrm{d}, \mathrm{H}-1, J_{1,2}=2.2 \mathrm{~Hz}\right), 4.17$ $\left(2 \mathrm{H}, \mathrm{t},-\mathrm{O}-\mathrm{CH}_{2^{-}}, J=6.6 \mathrm{~Hz}\right), 3.98\left(1 \mathrm{H}, \mathrm{d}, \mathrm{H}-5, J_{4,5}=9.0 \mathrm{~Hz}\right), 3.92\left(1 \mathrm{H}, \mathrm{t}, \mathrm{H}-4, J_{3,4}=J_{4,5}=8.9 \mathrm{~Hz}\right), 3.78$ $\left(1 \mathrm{H}, \mathrm{dd}, \mathrm{H}-2, J_{1,2}=2.3 \mathrm{~Hz}, J_{2,3}=3.3 \mathrm{~Hz}\right), 3.67\left(1 \mathrm{H}, \mathrm{dd}, \mathrm{H}-3, J_{2,3}=3.4 \mathrm{~Hz}, J_{3,4}=8.6 \mathrm{~Hz}\right), 3.40(3 \mathrm{H}, \mathrm{s}$, $\left.-\mathrm{O}-\mathrm{CH}_{3}\right), 1.68\left(2 \mathrm{H}, \mathrm{p},-\mathrm{O}-\mathrm{CH}_{2}-\mathrm{CH}_{2}-, J=6.6 \mathrm{~Hz}\right), 1.34\left(\mathrm{~m}, 10 \mathrm{H},-\left(\mathrm{CH}_{2}\right)_{5}-\mathrm{CH}_{3}\right), 0.89\left(\mathrm{~m}, 3 \mathrm{H},-\mathrm{CH}_{2}-\mathrm{CH}_{3}\right.$, $J=6.9 \mathrm{~Hz}) .{ }^{13} \mathrm{C}-\mathrm{NMR}\left(101 \mathrm{MHz}, \mathrm{MeOD}-d_{4}\right) \delta 171.5(\mathrm{C}=\mathrm{O}), 103.2(\mathrm{C}-1), 74.0(\mathrm{C}-5), 72.1(\mathrm{C}-3), 71.4(\mathrm{C}-2)$, $69.8(\mathrm{C}-4), 66.4\left(-\mathrm{O}-\mathrm{CH}_{2}-\right), 55.7\left(-\mathrm{O}-\mathrm{CH}_{3}\right), 32.9,30.3(2 \mathrm{C}), 29.6,26.9,23.7\left(-\mathrm{O}-\mathrm{CH}_{2}-\left(\mathrm{CH}_{2}\right)_{6}-\mathrm{CH}_{3}\right), 14.4$ $\left(-\mathrm{CH}_{3}\right)$. HRMS (ESI) $m / z$ cald for $\mathrm{C}_{15} \mathrm{H}_{28} \mathrm{O}_{7} \mathrm{Na}[\mathrm{M}+\mathrm{Na}]^{+} 343.1733$, found 343.1746 .

\subsection{Determination of Aqueous Solubility}

Firstly, the appearance of pure, synthesized molecules and the solubility area of the synthesized molecules in water were appreciated by visual observation at room temperature of about $25{ }^{\circ} \mathrm{C}$. For each molecule, several samples in 1-2 $\mathrm{mL}$ deionized water with various concentrations (between $0.01 \mathrm{mM}$ and $100 \mathrm{mM}$ ) were prepared by homogenizing at $500 \mathrm{rpm}$ with a standard magnetic hotplate stirrer MR 3001K (Heidolph Instruments, Schwabach, Germany) for $30 \mathrm{~min}$. The soluble or insoluble character was estimated on the aspect change of corresponding dispersion systems. The concentration limit to obtain an apparently clear solution was noted $[\mathrm{C}]_{\max }$. When solubilization does not occur at room temperature, a slow heating to $50{ }^{\circ} \mathrm{C}$ was applied under magnetic agitation. This allows the examination of the temperature-driven solubilization behavior and verifies the presence of the Krafft point (Tk), above which the surfactant solubility in water increases abruptly [37]. At Tk, solubility of the surfactant reaches its critical micelle concentration (CMC) [38]. In other words, Tk represents the critical temperature at which the micellization process occurs with the dissolution of hydrated surfactant crystals [39]. Thus, Tk can be precisely determined by differential scanning calorimetry (DSC), which has already been proposed by some authors [40,41]. All of the measurements were performed with a commercial $\mu \mathrm{DSC} 7$ evo calorimeter (SETARAM Instrumentation, Caluire, 
France). For each molecule, a sample with a concentrated aqueous mixture of $10 \%(w / w)$ molecule $\left(\mathrm{C}>>\mathrm{CMC}\right.$ ) was prepared at $50^{\circ} \mathrm{C}$ under magnetic agitation for $30 \mathrm{~min}$ to obtain a homogeneous and clear dispersion. These dispersions were then put into a refrigerator at $4{ }^{\circ} \mathrm{C}$ for a period over a week, permitting potential phase transitions, including the formation of equilibrated hydrated crystals. Samples of about $300 \mathrm{mg}$ were introduced in the calorimeter cell and equilibrated at $4{ }^{\circ} \mathrm{C}$ for $1 \mathrm{~h}$. A heating scan from $4{ }^{\circ} \mathrm{C}$ to $65{ }^{\circ} \mathrm{C}$ at a rate of $0.5^{\circ} \mathrm{C} / \mathrm{min}$ was then performed. Tk were identified as the onset of the endothermic signal detected by DSC during the dissolution of hydrated crystals. Tk were calculated as an average of at least two measurements.

\subsection{Determination of the Surface Activity}

The surface activity of the synthesized molecules was studied mainly in terms of their adsorption behavior on the air-aqueous solution interface. The equilibrium surface tensions $\gamma$ were measured by means of a Wilhelmy plate using a K100 Processor Tensiometer (KRUSS, Hamburg, Germany). The equilibrium surface tension $\gamma$ was plotted as a function of the log concentration for all molecules, from which we can derive various parameters, like critical micellar concentration (CMC) extrapolated from the break in the surface tension curve and surface tension at the CMC $\left(\gamma_{\mathrm{cmc}}\right)$. The surface excess $\left(\Gamma_{\max }\right)$ and minimal area per molecule at air-aqueous solution interface $\left(\mathrm{A}_{\min }\right)$ can be calculated from Gibbs equation for non-ionic surfactants:

$$
\Gamma_{\max }=-\frac{1}{2.303 R T}\left(\frac{d \gamma}{d \log c}\right)
$$

and

$$
\mathrm{A}_{\min }=\frac{10^{20}}{\mathrm{~N}_{\mathrm{A}} \Gamma_{\max }}
$$

where $R$ is the ideal gas constant $\left(8.31 \mathrm{~J} \cdot \mathrm{mol}^{-1} \mathrm{~K}^{-1}\right)^{\prime} \mathrm{T}$ is the measuring temperature $(\mathrm{K}) ; \gamma$ is the surface tension $\left(\mathrm{N} \cdot \mathrm{m}^{-1}\right)$, $\mathrm{c}$ is the concentration $\left(\mathrm{mol} \cdot \mathrm{L}^{-1}\right) ; \mathrm{A}_{\min }$ is the minimal area per molecule $\left(\AA^{2}\right)$; and $\mathrm{N}_{\mathrm{A}}$ is Avogadro's number $\left(6.02 \times 10^{23} \mathrm{~mol}^{-1}\right)$.

For each molecule, a series of solutions of different concentrations were prepared well above its Krafft Point, either at room temperature of about $25^{\circ} \mathrm{C}$ or at $50{ }^{\circ} \mathrm{C}$, under agitation in a water bath for $30 \mathrm{~min}$. Measurements were carried out for each concentration, either at $25^{\circ} \mathrm{C}$ for molecules with a Tk below room temperature, or at $\mathrm{T}>\mathrm{Tk}$ for those with higher Tk values than $25^{\circ} \mathrm{C}$. The standard deviation for temperature is $1^{\circ} \mathrm{C}$.

\section{Conclusions}

A new family of sugar-based surfactants was synthesized at the multigram scale using a simple and rapid two-step protocol from commercial methyl glycosides and characterized by physicochemical analyses. This methodology, which uses TEMPO-catalyzed oxidation and acid-catalyzed esterification, was applied to variable sugar heads (Glc, Gal, Man) and fatty alcohols (ethyl to lauryl alcohol) and led to the corresponding alkyl (1-methyl)uronates with moderate to good yields ( $44 \%-72 \%$ for two steps). The role of the chain length on the interfacial properties was evaluated at $25^{\circ} \mathrm{C}$ using $\mathrm{C}_{6}-\mathrm{C}_{12}$ derivatives of alkyl (1- $\alpha$-methyl)glucuronates. CMC values were shown to significantly decrease when the length of the chain increases, while $\gamma_{\mathrm{cmc}}$ slightly increases with the number of carbons of the alkyl chain. On the other hand, for a given alkyl chain length $\left(\mathrm{C}_{8}\right)$, sugar head nature (Gal, Glc, or Man) does not influence the interfacial properties. So, as yet observed for others sugar-based surfactants, a small variation in the alkyl chain length has a greater effect on the surface activity than the nature of the sugar head. This study reveals that these sugar esters are of particular interest, resulting in a significant reduction of the effective amount of molecules required to give a minimum surface tension of pure water, similar to corresponding alkylpolyglycosides or common polyoxyethylene nonionic surfactants. However, the proposed molecules present a limited micellar phase area, whatever the 
alkyl chain length or the nature of the sugar head. Indeed, the solubility limits to obtain a clear solution significantly decrease when the length of the chain increases. This point can be problematic for industrial applications and can lead to a decrease in the ease of their handing and formulating. Nevertheless, this work illustrates that anticipating the solubility properties of new amphiphilic molecules is tricky and challenging. The improvement of molecular structures and synthesis of new sugar ester surfactants should be investigated to enhance sugar ester solubility properties and explore their potential applications in accordance with specific industrial needs. For example, additional results indicate that synthesized sugar esters with a galactose sugar head enhance the solubility.

Supplementary Materials: The ${ }^{1} \mathrm{H}$ - and ${ }^{13} \mathrm{C}-\mathrm{NMR}$ spectral of compounds 2, 3a-3f, 4, 5, 6 and 7 are summarized in Supplementary Materials. Supplementary materials can be accessed at: http://www.mdpi.com/1420-3049/21/ $10 / 1301 /$ s1.

Acknowledgments: This work was performed, in partnership with the SAS PIVERT, within the frame of the French Institute for the Energy Transition (Institut pour la Transition Energétique (ITE) P.I.V.E.R.T. (www.institutpivert.com)) selected as an Investment for the Future ("Investissements d'Avenir"). This work was supported, as part of the Investments for the Future, by the French Government under the reference ANR-001-01. Huiling Lu acknowledges the Chinese Scholarship Council for the financial support of her PhD grant.

Author Contributions: A.D., A.W., G.P. and I.P. conceived and designed the experiments; H.L. performed the experiments; all authors analyzed the data, M.O. contributed reagents/materials/analysis tools; G.P. and A.D. were the major writers of the manuscript, which was proof-read by all the authors.

Conflicts of Interest: The authors declare no conflict of interest

\section{References}

1. Von Rybinski, W.; Hill, K. Alkyl polyglycosides-Properties and applications of a new class of surfactants. Angew. Chem. Int. Ed. 1998, 37, 1328-1345. [CrossRef]

2. Ruiz, C.C. Sugar-Based Surfactants: Fundamentals and Applications; CRC Press: Boca Raton, FL, USA, 2008; pp. 245-306.

3. Garcia, M.T.; Ribosa, L.; Campos, E.; Leal, J.S. Ecological properties of alkylglucosides. Chemosphere 1997, 35, $545-556$.

4. Stubenrauch, C. Sugar surfactants-Aggregation, interfacial, and adsorption phenomena. Curr. Opin. Colloid Int. Sci. 2001, 6, 160-170. [CrossRef]

5. Matsumura, S.; Imai, K.; Yoshikawa, S.; Kawada, K.; Uchibor, T. Structural activities, biodegradability and antimicrobial properties of n-alkyl glucosides, mannosides and galactosides. J. Am. Oil Chem. Soc. 1990, 67, 996-1001. [CrossRef]

6. Hill, K.; Rhode, O. Sugar-based surfactants for consumer products and technical applications. Fett-Lipid 1999, 101, 25-33. [CrossRef]

7. Baker, I.J.A.; Matthews, B.; Suares, H.; Krodkiewska, I.; Furlong, D.N.; Grieser, F.; Drummond, C.J. Sugar fatty acid ester surfactants: structure and ultimate aerobic biodegradability. J. Surf. Det. 2000, 3, 1-11. [CrossRef]

8. Ducret, A.; Giroux, A.; Trani, M.; Lortie, R. Enzymatic preparation of biosurfactants from sugars or sugar alcohols and fatty acids in organic media under reduced pressure. Biotechnol. Bioeng. 1995, 48, 214-221. [CrossRef] [PubMed]

9. Skagerlind, P.; Larsson, K.; Barfoed, M.; Hult, K. Glucoside ester synthesis in microemulsions catalyzed by Candida antartica component B lipase. J. Am. Oil Chem. Soc. 1997, 74, 39-42. [CrossRef]

10. Blecker, C.; Piccicuto, S.; Lognay, G.; Deroanne, C.; Marlier, M.; Paquot, M. Enzymatically prepared n-alkyl esters of glucuronic acid: The Effect of hydrophobic chain length on surface properties. J. Colloid Int. Sci. 2002, 247, 424-428. [CrossRef] [PubMed]

11. Moreau, B.; Lognay, G.C.; Blecker, C.; Brohée, J.C.; Chéry, F.; Rollin, P.; Paquot, M.; Marlier, M. Synthesis of novel D-glucuronic acid fatty esters using Candida antarctica lipase in tert-butanol. Biotechnol. Lett. 2004, 26, 419-424. [CrossRef] [PubMed]

12. Fukada, K.; Kawasaki, M.; Seimiya, T.; Abe, Y.; Fujiwara, M.; Ohbu, K. Stereochemical aspects of micellar properties of esterified glucoside surfactants in water: apparent molar volume, adiabatic compressibility, and aggregation number. Colloid Polym. Sci. 2000, 278, 576-580. [CrossRef] 
13. Dupuy, C.; Auvray, X.; Petipas, C.; Rico-Lattes, I.; Lattes, A. Anomeric effects on the structure of micelles of alkyl maltosides in water. Langmuir 1997, 13, 3965-3967. [CrossRef]

14. Razafindralambo, H.; Blecker, C.; Mezdour, S.; Deroanne, C.; Crowet, J.M.; Brasseur, R.; Lins, L.; Paquot, M. Impacts of the carbonyl group location of ester bond on interfacial properties of sugar-based surfactants: Experimental and computational evidences. J. Phys. Chem. B 2009, 113, 8872-8877. [CrossRef] [PubMed]

15. Hato, M.; Minamikawa, H.; Tamada, K.; Baba, T.; Tanabe, Y. Self-assembly of synthetic glycolipid/water systems. Adv. Colloid Int. Sci. 1999, 80, 233-270. [CrossRef]

16. Becerra, N.; Toro, C.; Zanacco, A.L.; Lemp, E.; Gunther, G. Characterization of micelles formed by sucrose 6-O-monoesters. Colloids Surf. A 2008, 327, 134-139. [CrossRef]

17. Garofalakis, G.; Murray, B.S.; Sarney, D.B. Surface activity and critical aggregation concentration of pure sugar esters with different sugar headgroups. J. Colloid Int. Sci. 2000, 229, 391-398. [CrossRef] [PubMed]

18. Patist, A.; Bhagwat, S.S.; Penfield, K.W.; Aikens, P.; Shah, D.O. On the measurement of critical micelle concentrations of pure and technical-grade nonionic surfactants. J. Surf. Det. 2000, 3, 53-58. [CrossRef]

19. Wadouachi, A.; Kovensky, J. Synthesis of glycosides of glucuronic, galacturonic and mannuronic acids: An overview. Molecules 2011, 16, 3933-3968. [CrossRef]

20. Lebedev, O.L.; Khidekel, E.G.; Razuvaev, G.A. Isotopic analysis of nitrogen by electron paramagnetic resonance method. Doklady Akademii Nauk SSR 1961, 140, 1327-1329.

21. Anelli, P. L.; Biffi, C.; Montanari, F.; Quici, S. Fast and selective oxidation of primary alcohols to aldehydes or to carboxylic acids and of secondary alcohols to ketones mediated by oxoammonium salts under two-phase conditions. J. Org. Chem. 1987, 52, 2559-2562. [CrossRef]

22. Zhao, M.; Li, J.; Mano, E.; Song, Z.; Tschaen, D.M.; Grabowski, E.J.J.; Reider, P.J. Oxidation of primary alcohols to carboxylic acids with sodium chlorite catalyzed by TEMPO and bleach. J. Org. Chem. 1999, 64, 2564-2566. [CrossRef]

23. Epp, J.B.; Widlanski, T. S. Facile preparation of nucleoside-5'-carboxylic acids. J. Org. Chem. 1999, 64, $293-295$. [CrossRef] [PubMed]

24. Richel, A.; Laurent, P.; Wathelet, B.; Wathelet, J.P.; Paquot, M. Microwave-assisted synthesis of D-glucuronic acid derivatives using cost-effective solid acid catalysts. Tetrahedron Lett. 2010, 51, 1356-1360. [CrossRef]

25. Abel, S.; Dupradeau, F.Y.; Raman, E.P.; MacKerell, A.D.; Marchi, M. Molecular simulations of dodecyl- $\beta$-maltoside micelles in water: Influence of the headgroup conformation and force field parameters. J. Phys. Chem. B 2011, 115, 487-499. [CrossRef] [PubMed]

26. Zhang, R.; Zhang, L.; Somasundaran, P. Study of mixtures of n-dodecyl- $\beta$-D-maltoside with anionic, cationic, and nonionic surfactant in aqueous solutions using surface tension and fluorescence techniques. J. Colloid Interface Sci. 2004, 278, 453-460. [CrossRef] [PubMed]

27. Boyd, B.J.; Drummond, C.J.; Krodkiewska, I.; Grieser, F. How chain length, headgroup polymerization, and anomeric configuration govern the thermotropic and lyotropic liquid crystalline phase behavior and the air-water interfacial adsorption of glucose-based surfactants. Langmuir 2000, 16, 7359-7367. [CrossRef]

28. Savelli, M.P.; van Roekeghem, P.; Douillet, O.; Cave, G.; Gode, P.; Ronco, G.; Villa, P. Effects of tail alkyl chain length (n), head group structure and junction $(Z)$ on amphiphilic properties of 1-Z-R-D,L-xylitol compounds $(\mathrm{R}=\mathrm{CnH} 2 \mathrm{n}+1)$. Int. J. Pharm. 1999, 182, 221-236. [CrossRef]

29. Wang, X.; Yu, L.; Jiao, J.; Zhang, H.; Wang, R.; Chen, H. Aggregation behavior of COOH-functionalized imidazolium-based surface active ionic liquids in aqueous solution. J. Mol. Liq. 2012, 173, 103-107. [CrossRef]

30. Rosen, M.J. Surfactants and Interfacial Phenomena, 3rd ed.; Wiley-Interscience: Hoboken, NJ, USA, $2004 ;$ p. 444.

31. Schmidt-Lassen, J.; Lindhorst, T.K. Exploring the meaning of sugar configuration in a supramolecular environment: Comparison of six octyl glycoside micelles by ITC and NMR spectroscopy. MedChemComm 2014, 5, 1218-1226. [CrossRef]

32. Lin, S.Y.; Lin, Y.Y.; Chen, E.M.; Hsu, C.T.; Kwan, C.C. A study of the equilibrium surface tension and the critical micelle concentration of mixed surfactant solutions. Langmuir 1999, 15, 4370-4376. [CrossRef]

33. Klammt, C.; Schwarz, D.; Lehnet, I.; Sobhanifar, S.; Loehr, F.; Zeelen, J.; Glaubitz, C.; Doetsch, V.; Bernhard, F. Cell-free expression of integral membrane proteins for structural studies. In Cell-Free Protein Synthesis; Wiley-VCH Verlag GmbH \& Co. KGaA: Darmstadt, Germany, 2008; pp. 141-164.

34. Klammt, C.; Schwarz, D.; Fendler, K.; Haase, W.; Doetsch, V.; Bernhard, F. Evaluation of detergents for the soluble expression of $\alpha$-helical and $\beta$-barrel-type integral membrane proteins by a preparative scale individual cell-free expression system. FEBS J. 2005, 272, 6024-6038. [CrossRef] [PubMed] 
35. Hait, S.K.; Moulik, S.P. Determination of critical micelle concentration (CMC) of nonionic surfactants by donor-acceptor interaction with lodine and correlation of CMC with hydrophile-lipophile balance and other parameters of the surfactants. J. Surf. Det. 2001, 4, 303-309. [CrossRef]

36. Lu, B.; Vayssade, M.; Miao, Y.; Chagnault, V.; Grand, E.; Wadouachi, A.; Postel, D.; Drelich, A.; Egles, C.; Pezron, I. Physico-chemical properties and cytotoxic effects of sugar-based surfactants: Impact of structural variations. Colloid. Surf. B Biointerface. 2016, 145, 79-86. [CrossRef] [PubMed]

37. Kunieda, H.; Shinoda, K. Krafft points, critical micelle concentrations, surface tension, and solubilizing power of aqueous solutions of fluorinated surfactants. J. Phys. Chem. 1976, 80, 2468-2470. [CrossRef]

38. Mazer, N.A.; Benedek, G.B.; Carey, M.C. An investigation of the micellar phase of sodium dodecyl sulfate in aqueous sodium chloride solutions using quasielastic light scattering spectroscopy. J. Phys. Chem. 1976, 80, 1075-1085. [CrossRef]

39. Manet, S.; Karpichev, Y.; Dedovets, D.; Oda, R. Effect of Hofmeister and alkylcarboxylate anionic counterions on the Krafft temperature and melting temperature of cationic gemini surfactants. Langmuir 2013, 29, 3518-3526. [CrossRef] [PubMed]

40. Pestman, J.M.; Terpstra, K.R.; Stuart, M.C.A.; van Doren, H.A.; Brisson, A.; Kellogg, R.M.; Engberts, J.B.F.N. Nonionic bolaamphiphiles and gemini surfactants based on carbohydrates. Langmuir 1997, 13, 6857-6860. [CrossRef]

41. Matsuki, H.; Ichikawa, R.; Kaneshina, S.; Kamaya, H.; Ueda, I. Differential Scanning Calorimetric Study on the Krafft Phenomenon of Local Anesthetics. J. Colloid Interface Sci. 1996, 181, 362-369. [CrossRef]

Sample Availability: Not Available.

(C) 2016 by the authors; licensee MDPI, Basel, Switzerland. This article is an open access article distributed under the terms and conditions of the Creative Commons Attribution (CC-BY) license (http://creativecommons.org/licenses/by/4.0/). 